\title{
Prehl’ad krúžkovania vtákov na Slovensku za rok 2019
}

\author{
Bird-ringing results in Slovakia in 2019
}

\section{Michal Jenčo \& Matej RePEL}

Slovenská ornitologická spoločnost'/BirdLife Slovensko, Krúžkovacia centrála, Námestie osloboditel'ov 1, 07101 Michalovce, e-mail: kruzkysk@gmail.com

\begin{abstract}
In 2019, 86 ringers ringed altogether 59472 birds, of them 5641 were nestlings. That number was 1,58\% (90) higher compare to 2018. The ringed birds belonged to 151 species. The most numerous ringed species were Barn Swallow (Hirundo rustica, 7324 ind.) Blackcap (Sylvia atricapilla, 7212 ind.), Great Tit (Parus major, 5322 ind.), European robin (Erithacus rubecula, 4813 ind.), Blue Tit (Cyanistes caeruleus 3973 ind.). The colour ringed schemes in Slovakia are given. Altogether 553 foreign recoveries were registered, out of them were 193 individuals ringed abroad and re-trapped in Slovakia and, 360 individuals ringed in Slovakia and re-trapped abroad.
\end{abstract}

Key words: bird ringing, recoveries, colour ringing schemes

\section{Úvod}

Táto správa zahŕňa všetky výsledky za rok 2019, ktoré krúžkovatelia spracovali a následne zaslali „KC“. Krúžkovanie sa vykonávalo na základe rozhodnutí Ministerstva životného prostredia Slovenskej republiky o povolení výnimiek zo zákona č.543/2002 Z.z. o ochrane prírody a krajiny. Výnimka (rozhodnutie č. 3320/2019-6.3 zo dňa 08.04.2019) oprávňuje na krúžkovanie všetkých druhov vtákov okrem vybraných druhov, napr. niektorých sov, dravcov, volaviek a pod. Na základe výnimky (rozhodnutie č. 664/297/05-5.1 pil) sa umožňuje členom združenia Ochrana dravcov na Slovensku výskum dravcov a sov vrátane ich krúžkovania.

Celkovo evidujeme 86 krúžkovatelov spĺnajúcich kritériá pre udelenie licencie na krúžkovanie vtáctva a teda oprávnených využívat' výnimky. V roku 2019 z nich využilo výnimku a vol’ne žijúce vtáky odchytávalo a okrúžkovalo 51 krúžkovatelov, ktorí zapísali svoje krúžkovacie údaje za rok 2019 do online databázy Rings. Niekolko krúžkovatelov avizovalo, že v roku 2019 nekrúžkovalo. Na stránke www.vtaky.sk zverejňujeme aktuálny zoznam krúžkovatelov oprávnených vykonávat’ krúžkovatel'skú činnosţ na základe výnimky spolu s prideleným typom licencie.

V roku 2019 sa krúžkovatelia zapojili do viacerých projektov (Operačný program životné prostredie, vedecko-výskumné projekty VEGA, projekty cezhraničnej spolupráce, LIFE projekty...). Išlo napríklad o krúžkovanie metodikou CES na 8 stacionároch (Drienovec, Gbelce, Dolné Vestenice, Kiarovský močiar, Senné, Slanica, Sabinov - strelnica a Bešeňová) zameranie na konkrétne druhy (napr. rybárik riečny, lastovička obyčajná). Ornitologický stacionár Drienovec je zaradený do medzinárodnej siete SEEN. Stále viac sa do popredia dostáva aj 
farebné značenie. Tento spôsob je bez pochýb efektívnejším pri získavaní spätných hlásení.

$\mathrm{KC}$ funguje nad’alej s finančnou a materiálnou podporou SOS/BirdLife Slovensko $\mathrm{v}$ priestoroch kancelárie $\mathrm{v}$ Michalovciach pod vedením Mateja Repela a spolupracovníkmi Michalom Jenčom a Miroslavom Demkom. Väčšina krúžkovatel'ov vykonáva krúžkovanie na vlastné náklady a vo svojom volnom čase.

\section{Výsledky}

\section{Krúžkovanie}

V roku 2019 sa okrúžkovalo o 930 vtákov viac ako v roku 2018 (58 542 ex.). Označených bolo spolu 59472 jedincov zo 151 druhov vtákov (rok 2018, 149 druhov) (príloha 1). Najčastejšie krúžkovanými druhmi boli v roku 2019 lastovička obyčajná (H. rustica) 7324 ex., penica čiernohlavá (S. atricapilla) 7212 ex., sýkorka vel'ká (P. major) 5322 ex., červienka obyčajná (E. rubecula) 4813 ex. a sýkorka belasá (C. caeruleus) 3979 ex. (tab.1) Označených bolo 5641 mlád'at. Najviac mlád'at bolo okrúžkovaných u druhu sýkorka vel'ká (P. major) 1374 ex. Nasledovali sokol myšiar (Falco tinnunculus) 704 ex., bocian biely (Ciconia ciconia) 695 ex., muchárik bielokrký (Ficedula albicollis) 586 ex. a vodnár potočný (Cinclus cinclus) 351 ex. (tab. 2). Celkovo bolo okrúžkovaných 56859 spevavcov a 2613 nespevavcov. Medzi najpočetnejšie nespevavce patrili. F. tinnunculus (715), C. ciconia (703) a Alcedo atthis (114).

Krúžkovanie na Slovensku má v rokoch 2008 - 2019 mierne vzrastajúci trend, v posledných 4 rokoch je počet krúžkovaných vtákov pomerne vyrovnaný (obr. 1). Kompletné výsledky okrúžkovaných vtákov s počtom mlád’at a spätných hlásení sú v prílohe 1.

V roku 2019 bolo okrúžkovaných viac samcov (11 455) ako samíc (8 661). U 39356 jedincov nebolo určené pohlavie (obr. 2). Z hladiska vekového zloženia majoritu tvorili $1 \mathrm{~K}$ vtáky, v prvom roku života (31 459). Nasledujú +1K jedince (11 473), teda vtáky minimálne v druhom roku života a staršie (obr. 3).
Spätné hlásenia

V roku 2019 sa zaevidovalo spolu 6238 spätných hlásení ( 96 druhov), z ktorých 5628 hlásení bolo domácich v rámci Slovenska ( 93 druhov). Medzi 10 najčastejšie retrapovaných druhov sa dostalo 9 spevavcov a čajka bielohlavá (121) (tab. 3). V evidencii sa nachádza 193 hlásení vtákov krúžkovaných v zahraničí a odčítaných resp. odchytených na území Slovenska („,cudzie“ typ „C“). Už tradične najviac vtákov sa identifikovalo s mad'arskými krúžkami a to až v 75 prípadoch, druhé bolo Pol'sko s 48 krúžkovancami a prvú trojicu uzatvára Rakúsko s 18 krúžkovancami (obr. 4). Úzko to súvisí s geografickou polohou, aktivitou tamojších krúžkovatel'ov, ale aj dobrou spoluprácou s týmito centrálami, kde dochádza k takmer okamžitej výmene údajov. Spolu sa na Slovensku podarilo identifikovat' vtáky z 13 krúžkovacích schém z 12 krajín.

Za rok 2019 KC eviduje 360 tzv. „Z“ (zahraničných) hlásení. Sú to jedince krúžkované na našom území a odčítané resp. odchytené v inej krajine. Najviac hlásení sme dostali z Mad’arska (140), nasleduje Pol'sko (120) a Česká republika (45). Hlásenia o slovenských krúžkovancoch pochádzajú z 22 krajín (obr. 5).

Spätné hlásenia boli získané za 33 rôznych okolností nálezu vtáka (tab. 4). Najčastejšie boli vtáky odchytené (5 487 jedincov), podla farebného krúžku bolo identifikovaných 343 jedincov. Ornitologický krúžok bol odčítaný bez chytenia vtáka u 231 jedincov.

\section{Pod'akovanie}

Pod'akovanie patrí všetkým, ktorí si splnili svoju povinnost' a v stanovenom čase zaslali výsledky z krúžkovania spracované v programe RINGS čím umožnili spracovanie nielen tejto správy. Ďakujeme mnohým slovenským a zahraničným nálezcom a pozorovatel'om, ktorí zaslali údaje o spätných hláseniach a za spoluprácu všetkým zahraničným krúžkovacím centrálam. Ďakujeme aj koordinátorom programov farebného značenia za pomoc a koordináciu.

Došlo: 1.11 .2020

Akceptované: 31. 1. 2021

Online 28. 2. 2021 
Tab. 1. Desat' najviac krúžkovaných druhov za rok 2019 na Slovensku.

Tab. 1. Top ten most ringed species in 2019 in Slovakia.

\begin{tabular}{lc}
\hline Druh I & $\begin{array}{c}\text { Počet ex. I } \\
\text { Species }\end{array}$ \\
\hline Hirundo rustica & 7324 \\
Sylvia atricapilla & 7212 \\
Parus major & 5322 \\
Erithacus rubecula & 4813 \\
Cyanistes caeruleus & 3979 \\
Prunella modularis & 2892 \\
Phylloscopus collybita & 2535 \\
Acrocephalus schoenobaenus & 1589 \\
Acrocephalus scirpaceus & 1583 \\
Riparia riparia & 1056 \\
\hline
\end{tabular}

Tab. 2. Desat' najviac krúžkovaných druhov na hniezde (pull.) v roku 2019 na Slovensku.

Tab. 2. Top ten most ringed species as pullus in 2019 in Slovakia.

\begin{tabular}{lc}
\hline Druh / & Počet ex. I \\
Species & No. of ind. \\
\hline Parus major & 1374 \\
Falco tinnunculus & 704 \\
Ciconia ciconia & 695 \\
Ficedula albicollis & 586 \\
Cinclus cinclus & 351 \\
Hirundo rustica & 329 \\
Cyanistes caeruleus & 316 \\
Sitta europaea & 107 \\
Phoenicurus ochruros & 100 \\
Acrocephalus arundinaceus & 93 \\
\hline
\end{tabular}

Tab. 3. Desat' najviac znovu odchytených druhov v roku 2019 na Slovensku.

Tab. 3. Ten most re-trapped species in 2019 in Slovakia.

\begin{tabular}{lc}
\hline Druh/ & $\begin{array}{c}\text { Spätné hlásenia/ } \\
\text { Recoveries }\end{array}$ \\
\hline Erithacus rubecula & 1486 \\
Parus major & 715 \\
Sylvia atricapilla & 565 \\
Cyanistes caeruleus & 476 \\
Riparia riparia & 254 \\
Turdus merula & 186 \\
Acrocephalus scirpaceus & 154 \\
Poecile palustris & 124 \\
Phylloscopus collybita & 122 \\
Larus cachinnans & 121 \\
\hline
\end{tabular}

Tab. 4. Okolnosti nálezu vtáka pri spätných hláseniach. Okolnosti nálezu - kód:

Tab. 4. Finding circumstances of recovery bird reports. Finding circumstances - code: $00=$ Found, $01=$ Bird found, $02=$ Ring only found, $08=$ Ringing casualty, $10=$ Shot, $11=$ Found shot, $19=$ Hunted, 20 = Intentionally taken, $28=$ Metal ring read in field, $29=$ Colour mark record, $35=$ Electrocuted, 37 = Poisoned: poison identified, $38=$ Poisoned: poison not identified, $40=$ Road casualty, $42=$ Aircraft casualty, $43=$ Hit wires, 44 = Hit glass, $46=$ Entered building, $50=$ Injured, 56 = Botulism, $58=$ Sick, $61=$ Taken by cat, $70=$ Drowned, 75 $=$ Hot weather, 81 = Identified from leg ring(s), 82 = Identified from neck ring(s).

\begin{tabular}{|c|c|c|}
\hline $\begin{array}{l}\text { Kód / } \\
\text { Code }\end{array}$ & Okolnosti nálezu vtáka & $\begin{array}{c}\text { Počet } \\
\text { jedincov / } \\
\text { No. } \\
\text { of ind. }\end{array}$ \\
\hline$\overline{0}$ & Nájdený, bez bližších údajov & 5 \\
\hline 1 & Nájdený mítvy & 21 \\
\hline 2 & Nájdený iba krúžok & 3 \\
\hline 3 & Nájdená iba noha s krúžkom & 2 \\
\hline 8 & $\begin{array}{l}\text { Mŕtvy alebo zranený pri odchyte, } \\
\text { krúžkovaní }\end{array}$ & 35 \\
\hline 10 & Strelený & 5 \\
\hline 19 & Ulovený, pravdepodobne zastrelený & 1 \\
\hline 20 & Chytený & 5487 \\
\hline 26 & Chytený pretože bol krúžkovaný & 1 \\
\hline 27 & Nájdený mítvy v búdke & 1 \\
\hline 28 & $\begin{array}{l}\text { Kovový krúżok odčitaný bez chytenia } \\
\text { vtáka }\end{array}$ & 231 \\
\hline 29 & $\begin{array}{l}\text { Identifikácia na základe farebnej } \\
\text { značky }\end{array}$ & 6 \\
\hline 35 & Zasiahnutý elektrickým prúdom & 16 \\
\hline 38 & Otrávený neznámou chemickou látkou & 3 \\
\hline 40 & Nájdený na ceste, zrazený autom & 4 \\
\hline 41 & Nájdený na železnici, zrážka s vlakom & 1 \\
\hline 42 & Zrážka s lietadlom & 2 \\
\hline 43 & Náraz na drôty & 9 \\
\hline 44 & Náraz na sklo & 4 \\
\hline 45 & Náraz na budovu, most a pod. & 3 \\
\hline 46 & Nájdený vo vnútri budovy & 2 \\
\hline 49 & $\begin{array}{l}\text { Utopeny v malej vodnej nádrži } \\
\text { (bazén, sud) }\end{array}$ & 1 \\
\hline 50 & Zranenie nezavinené človekom & 1 \\
\hline 58 & Ochorenie z neznámych príčin & 1 \\
\hline 61 & Chytený mačkou & 3 \\
\hline 64 & Chytený sovou alebo dravcom & 1 \\
\hline 71 & Zamotaný v prírodnom materiály & 1 \\
\hline 74 & Vyčerpanie vplyvnom nízkych teplôt & 1 \\
\hline 76 & Vyčerpanie nedostatkom potravy, vody & 2 \\
\hline 81 & Identifikácia podl'a farebných krúžkov & 343 \\
\hline 82 & Identifikácia podl'a límca & 40 \\
\hline 83 & identifikácia podl'a krídlovej značky & 1 \\
\hline 85 & Identifikácia podl'a satelitnej vysielačky & 1 \\
\hline
\end{tabular}




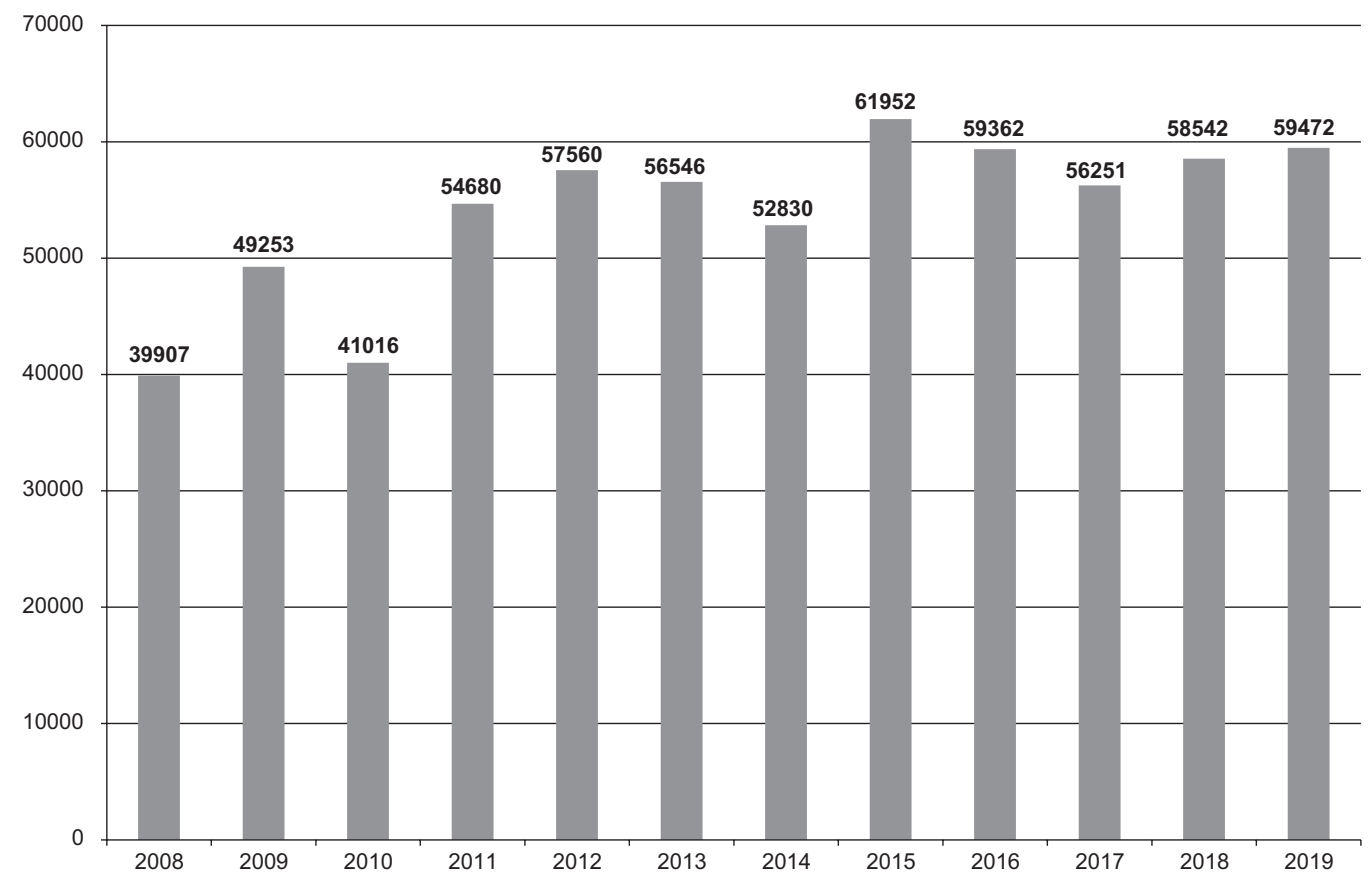

Obr. 1. Počet okrúžkovaných vtákov v rokoch 2008 - 2019 na Slovensku.

Fig. 1. Number of ringed birds in Slovakia in 2008- 2019.

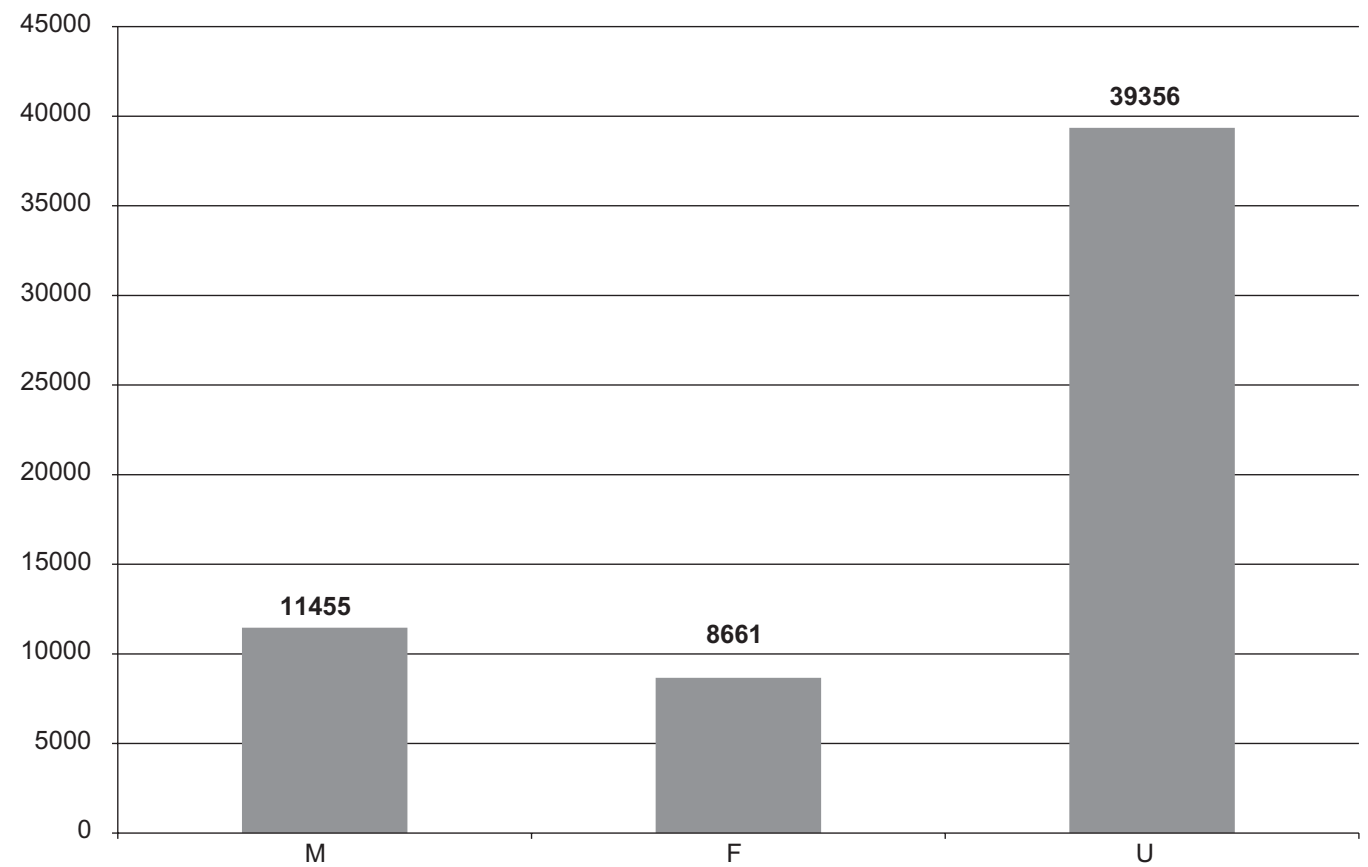

Obr. 2. Zastúpenie pohlaví vtákov krúžkovaných na Slovensku v roku 2019 v počtoch jedincov $(\mathrm{M}=\mathrm{samce}, \mathrm{F}=$ samice, $\mathrm{U}=$ neznámy).

Fig. 2. Sex of ringed birds in Slovakia in 2019 in number of individuals ( $M=$ males, $F=$ females, $U=$ unknown). 




Obr. 3. Podiel vekových kategórií okrúžkovaných vtákov (pull. - mlád’atá, f.g. - plne vyvinuté, $1 \mathrm{~K}-1$. kalendárny rok života, $+1 \mathrm{~K}$ - starší ako $\vee 1$. kalendárnom roku života, $2 \mathrm{~K}-\mathrm{v} 2$. kalendárnom roku života, $+2 \mathrm{~K}-$ starší ako $\vee 2$. roku života, $3 \mathrm{~K}-$ v 3. kalendárnom roku života, $+3 \mathrm{~K}-$ starší ako v 3. roku života).

Fig. 3. Age categories of the ringed birds (pull. - young, $1 K-1$ st calendar year, $+1 K-$ older than 1 st calendar year, $2 K-2 n d$ calendar year, $+2 K-$ older than $2 n d$ calendar year, $3 K-3 r d$ calendar year, $+3 K-$ older than $3 r d$ calendar year).

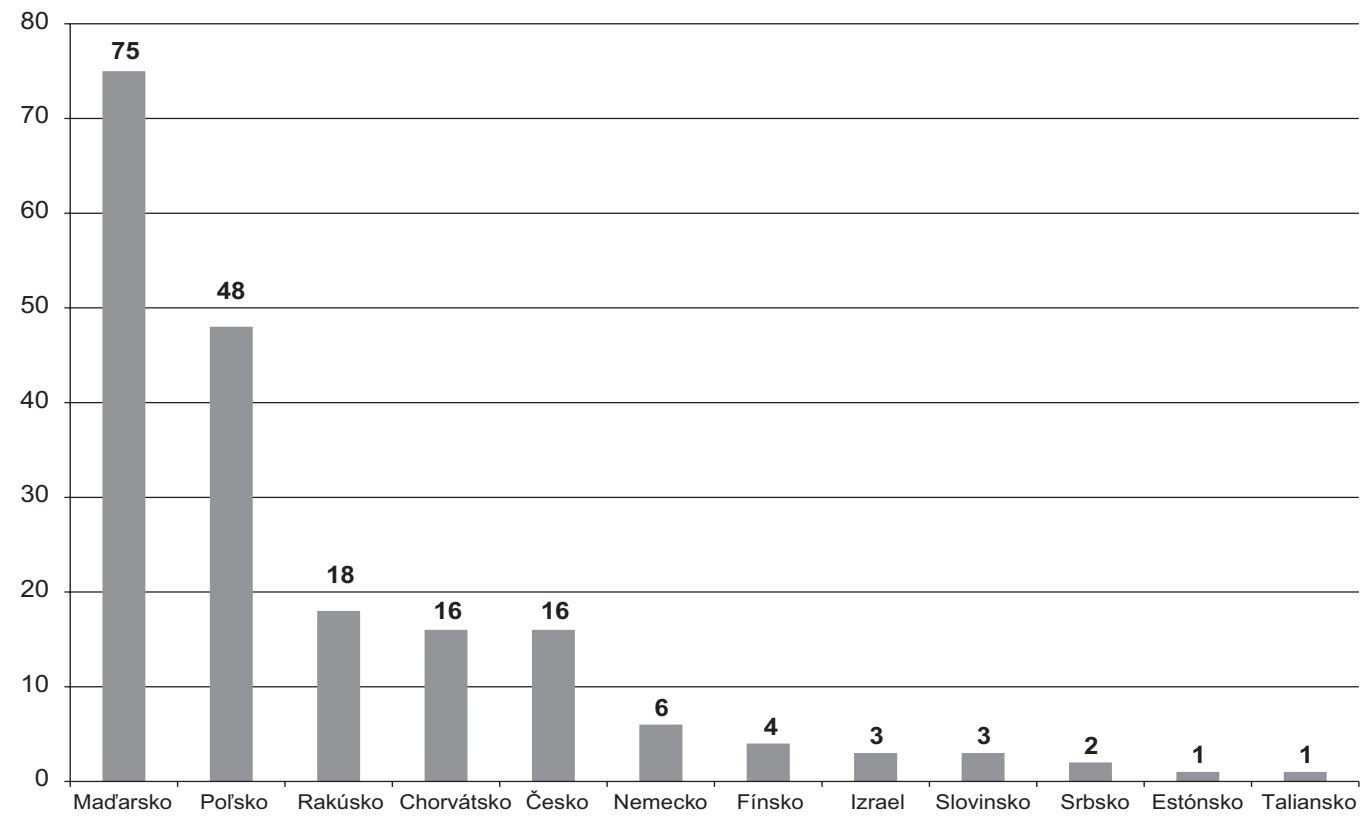

Obr. 4. Počet zahraničných krúžkovancov odchytených alebo odčítaných na Slovensku v roku 2019 - tzv. „C“ hlásenia.

Fig. 4. Number of birds ringed by foreign ringing schemes recovered in Slovakia in 2019 - „C" recoveries (Hungary, Poland, Austria, Croatia, Czech Republic, Germany, Finland, Israel, Slovenia, Serbia, Estonia, Italy). 


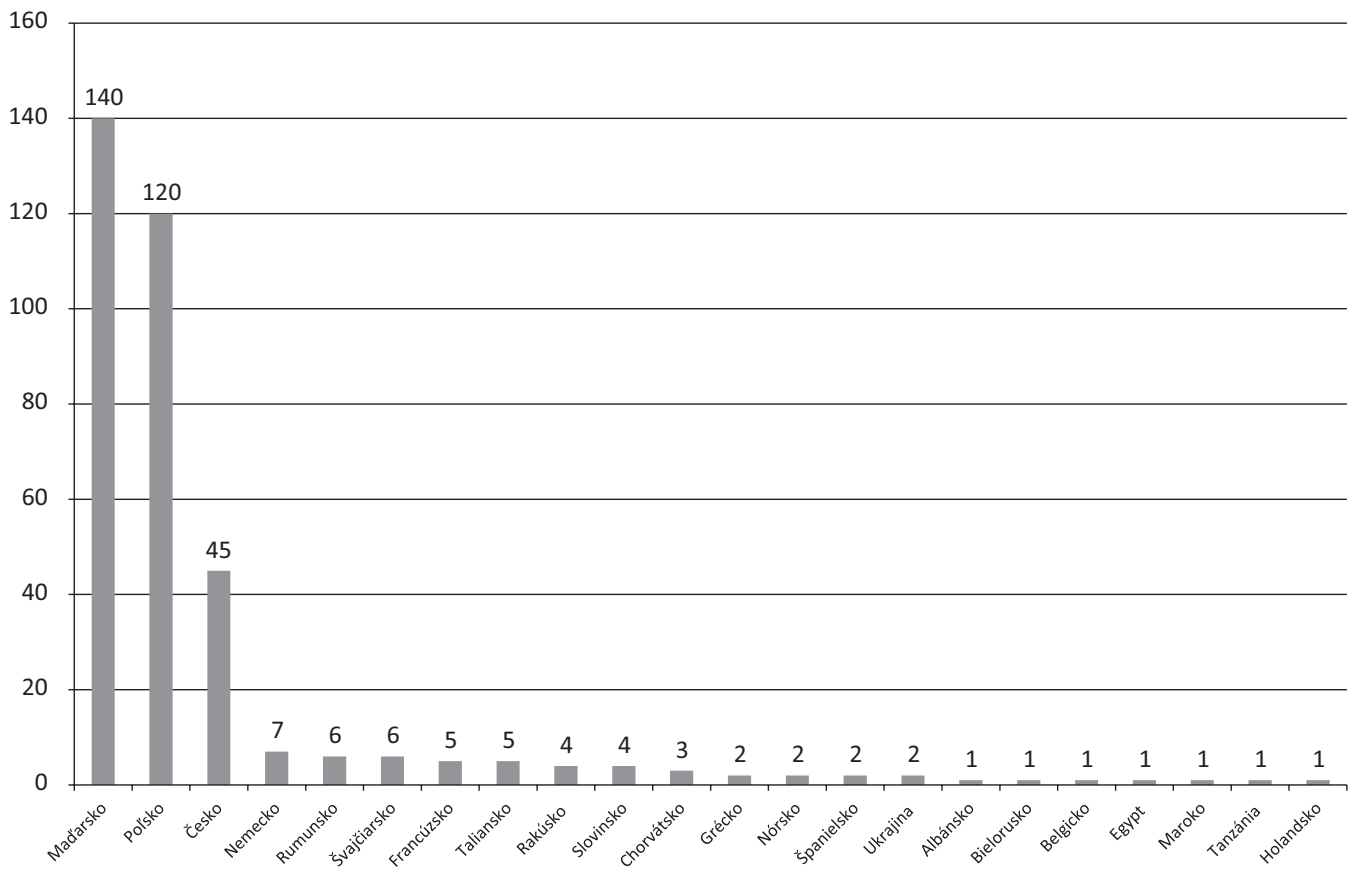

Obr. 5. Počet slovenských krúžkovancov odchytených alebo odčítaných v zahraničí v roku 2019 - tzv. „Z“ hlásenia.

Fig. 5. Number of birds ringed in Slovakia recovered abroad in 2019 - „Z“ recoveries (Hungary, Poland, Czech Republic, Germany, Romania, Switzerland, France, Italy, Austria, Slovenia, Croatia, Greece, Norway, Spain, Ukraine, Albania, Belarus, Belgium, Egypt, Morocco, Tanzania, Netherlands).

Príloha 1. Súhrnné výsledky krúžkovania vtákov na Slovensku v r. 2019 (pull. - mlád’atá, f.g. - plne vyvinuté, D\% - dominancia krúžkovaných druhov, SH - spätné hlásenia).

Appendix 1. Summary of bird ringing in Slovakia in 2019 (pull. - young, f. g. - full grown, D\% - ringed birds species dominance, $\mathrm{SH}$ - recoveries).

\begin{tabular}{lccccc}
\hline Druh / Species & $\Sigma$ & pull & f.g. & D \% & SH \\
\hline Hirundo rustica & 7324 & 329 & 6995 & 12,32 & 87 \\
Sylvia atricapilla & 7212 & 11 & 7201 & 12,13 & 565 \\
Parus major & 5322 & 1374 & 3948 & 8,95 & 715 \\
Erithacus rubecula & 4813 & 5 & 4808 & 8,09 & 1486 \\
Cyanistes caeruleus & 3979 & 316 & 3663 & 6,69 & 476 \\
Prunella modularis & 2892 & 0 & 2892 & 4,86 & 97 \\
Phylloscopus collybita & 2535 & 6 & 2529 & 4,26 & 122 \\
Acrocephalus schoenobaenus & 1589 & 0 & 1589 & 2,67 & 74 \\
Acrocephalus scirpaceus & 1583 & 4 & 1579 & 2,66 & 154 \\
Riparia riparia & 1056 & 0 & 1056 & 1,78 & 254 \\
Anthus trivialis & 850 & 0 & 850 & 1,43 & 1 \\
Fringilla coelebs & 831 & 5 & 826 & 1,40 & 20 \\
Phylloscopus trochilus & 806 & 0 & 806 & 1,36 & 39 \\
Carduelis carduelis & 803 & 1 & 802 & 1,35 & 57 \\
Ficedula albicollis & 717 & 586 & 131 & 1,21 & 22 \\
Carduelis spinus & 717 & 0 & 717 & 1,21 & 13 \\
Falco tinnunculus & 715 & 704 & 11 & 1,20 & 9 \\
Ciconia ciconia & 703 & 695 & 8 & 1,18 & 107 \\
Carduelis chloris & 698 & 0 & 698 & 1,17 & 20 \\
Emberiza schoeniclus & 696 & 0 & 696 & 1,17 & 33 \\
Sylvia communis & 695 & 0 & 695 & 1,17 & 45 \\
Turdus merula & 660 & 32 & 628 & 1,11 & 186 \\
Sturnus vulgaris & 589 & 72 & 517 & 0,99 & 2 \\
Regulus regulus & 582 & 582 & 0,98 & 3 \\
Acrocephalus palustris & 569 & 0 & 569 & 0,96 \\
\hline
\end{tabular}


Pokračovanie Prílohy 1. / Continuation of Appendix 1.

\begin{tabular}{|c|c|c|c|c|c|}
\hline Druh / Species & $\Sigma$ & pull & f.g. & $\mathrm{D} \%$ & $\mathrm{SH}$ \\
\hline Sylvia borin & 528 & 1 & 527 & 0,89 & 31 \\
\hline Sylvia curruca & 500 & 0 & 500 & 0,84 & 39 \\
\hline Turdus philomelos & 489 & 5 & 484 & 0,82 & 34 \\
\hline Aegithalos caudatus & 460 & 0 & 460 & 0,77 & 72 \\
\hline Periparus ater & 445 & 50 & 395 & 0,75 & 24 \\
\hline Phoenicurus ochruros & 443 & 100 & 343 & 0,74 & 30 \\
\hline Serinus serinus & 434 & 1 & 433 & 0,73 & 1 \\
\hline Pyrrhula pyrrhula & 402 & 0 & 402 & 0,68 & 65 \\
\hline Troglodytes troglodytes & 390 & 4 & 386 & 0,66 & 57 \\
\hline Emberiza citrinella & 381 & 0 & 381 & 0,64 & 31 \\
\hline Cinclus cinclus & 366 & 351 & 15 & 0,62 & 9 \\
\hline Locustella Iuscinioides & 312 & 2 & 310 & 0,52 & 38 \\
\hline Acrocephalus arundinaceus & 302 & 93 & 209 & 0,51 & 38 \\
\hline Passer montanus & 281 & 51 & 230 & 0,47 & 13 \\
\hline Coccothraustes coccothraustes & 278 & 2 & 276 & 0,47 & 10 \\
\hline Lanius collurio & 251 & 0 & 251 & 0,42 & 19 \\
\hline Muscicapa striata & 245 & 19 & 226 & 0,41 & 5 \\
\hline Motacilla flava & 228 & 0 & 228 & 0,38 & 2 \\
\hline Poecile palustris & 220 & 0 & 220 & 0,37 & 124 \\
\hline Sitta europaea & 199 & 107 & 92 & 0,33 & 56 \\
\hline Luscinia megarhynchos & 196 & 0 & 196 & 0,33 & 32 \\
\hline Panurus biarmicus & 191 & 0 & 191 & 0,32 & 18 \\
\hline Certhia familiaris & 168 & 0 & 168 & 0,28 & 50 \\
\hline Remiz pendulinus & 161 & 0 & 161 & 0,27 & 9 \\
\hline Delichon urbica & 148 & 6 & 142 & 0,25 & 0 \\
\hline Dendrocopos major & 140 & 6 & 134 & 0,24 & 44 \\
\hline Alcedo atthis & 114 & 63 & 51 & 0,19 & 8 \\
\hline Carduelis cannabina & 114 & 5 & 109 & 0,19 & 2 \\
\hline Regulus ignicapillus & 112 & 0 & 112 & 0,19 & 4 \\
\hline Poecile montanus & 98 & 9 & 89 & 0,16 & 13 \\
\hline Jynx torquilla & 87 & 34 & 53 & 0,15 & 2 \\
\hline Passer domesticus & 83 & 12 & 71 & 0,14 & 1 \\
\hline Motacilla alba & 81 & 17 & 64 & 0,14 & 1 \\
\hline Phoenicurus phoenicurus & 79 & 0 & 79 & 0,13 & 1 \\
\hline Circus aeruginosus & 75 & 75 & 0 & 0,13 & 5 \\
\hline Falco vespertinus & 73 & 73 & 0 & 0,12 & 9 \\
\hline Tyto alba & 71 & 48 & 23 & 0,12 & 2 \\
\hline Garrulus glandarius & 67 & 0 & 67 & 0,11 & 8 \\
\hline Hippolais icterina & 65 & 0 & 65 & 0,11 & 1 \\
\hline Ficedula hypoleuca & 62 & 0 & 62 & 0,10 & 1 \\
\hline Merops apiaster & 60 & 0 & 60 & 0,10 & 1 \\
\hline Falco cherrug & 59 & 59 & 0 & 0,10 & 5 \\
\hline Locustella naevia & 53 & 0 & 53 & 0,09 & 2 \\
\hline Turdus pilaris & 52 & 17 & 35 & 0,09 & 0 \\
\hline Locustella fluviatilis & 45 & 0 & 45 & 0,08 & 1 \\
\hline Larus cachinnans & 41 & 41 & 0 & 0,07 & 121 \\
\hline Apus apus & 41 & 37 & 4 & 0,07 & 1 \\
\hline Cygnus olor & 41 & 0 & 41 & 0,07 & 32 \\
\hline Asio otus & 40 & 34 & 6 & 0,07 & 0 \\
\hline Lophophanes cristatus & 40 & 0 & 40 & 0,07 & 10 \\
\hline Acrocephalus melanopogon & 37 & 0 & 37 & 0,06 & 3 \\
\hline Phylloscopus sibilatrix & 34 & 0 & 34 & 0,06 & 0 \\
\hline Aquila heliaca & 32 & 32 & 0 & 0,05 & 3 \\
\hline Motacilla cinerea & 30 & 10 & 20 & 0,05 & 0 \\
\hline Saxicola rubicola & 29 & 0 & 29 & 0,05 & 2 \\
\hline Luscinia luscinia & 28 & 0 & 28 & 0,05 & 5 \\
\hline Fringilla montifringilla & 26 & 0 & 26 & 0,04 & 0 \\
\hline Strix aluco & 25 & 19 & 6 & 0,04 & 0 \\
\hline Sylvia nisoria & 24 & 0 & 24 & 0,04 & 2 \\
\hline Bubo bubo & 22 & 22 & 0 & 0,04 & 0 \\
\hline Dendrocopos minor & 20 & 0 & 20 & 0,03 & 3 \\
\hline Clanga pomarina & 19 & 19 & 0 & 0,03 & 4 \\
\hline Emberiza cia & 19 & 0 & 19 & 0,03 & 1 \\
\hline Dendrocopos medius & 18 & 0 & 18 & 0,03 & 9 \\
\hline Picus viridis & 18 & 2 & 16 & 0,03 & 2 \\
\hline Accipiter nisus & 17 & 1 & 16 & 0,03 & 0 \\
\hline Anthus pratensis & 17 & 0 & 17 & 0,03 & 0 \\
\hline Caprimulgus europaeus & 16 & 0 & 16 & 0,03 & 1 \\
\hline Aquila chrysaetos & 16 & 16 & 0 & 0,03 & 3 \\
\hline Saxicola rubetra & 16 & 0 & 16 & 0,03 & 0 \\
\hline
\end{tabular}


Pokračovanie Prílohy 1. / Continuation of Appendix 1.

\begin{tabular}{|c|c|c|c|c|c|}
\hline Druh / Species & $\Sigma$ & pull & f.g. & $\mathrm{D} \%$ & $\mathrm{SH}$ \\
\hline Falco peregrinus & 15 & 15 & 0 & 0,03 & 0 \\
\hline Turdus iliacus & 14 & 0 & 14 & 0,02 & 0 \\
\hline Ficedula parva & 14 & 0 & 14 & 0,02 & 0 \\
\hline Buteo buteo & 14 & 0 & 14 & 0,02 & 0 \\
\hline Carpodacus erythrinus & 12 & 0 & 12 & 0,02 & 1 \\
\hline Oriolus oriolus & 12 & 0 & 12 & 0,02 & 0 \\
\hline Corvus monedula & 9 & 7 & 2 & 0,02 & 0 \\
\hline Ixobrychus minutus & 8 & 0 & 8 & 0,01 & 2 \\
\hline Rallus aquaticus & 8 & 0 & 8 & 0,01 & 0 \\
\hline Tringa glareola & 8 & 0 & 8 & 0,01 & 0 \\
\hline Haliaeetus albicilla & 8 & 8 & 0 & 0,01 & 1 \\
\hline Luscinia svecica & 8 & 0 & 8 & 0,01 & 0 \\
\hline Anser anser & 7 & 0 & 7 & 0,01 & 5 \\
\hline Certhia brachydactyla & 7 & 0 & 7 & 0,01 & 1 \\
\hline Dendrocopos syriacus & 6 & 0 & 6 & 0,01 & 1 \\
\hline Upupa epops & 6 & 5 & 1 & 0,01 & 0 \\
\hline Columba palumbus & 6 & 5 & 1 & 0,01 & 0 \\
\hline Crex crex & 6 & 0 & 6 & 0,01 & 0 \\
\hline Porzana porzana & 6 & 0 & 6 & 0,01 & 0 \\
\hline Gallinago gallinago & 6 & 0 & 6 & 0,01 & 1 \\
\hline Streptopelia decaocto & 5 & 0 & 5 & 0,01 & 0 \\
\hline Athene noctua & 5 & 0 & 5 & 0,01 & 0 \\
\hline Luscinia svecica cyanecula & 5 & 0 & 5 & 0,01 & 0 \\
\hline Falco subbuteo & 5 & 4 & 1 & 0,01 & 0 \\
\hline Loxia curvirostra & 4 & 0 & 4 & 0,01 & 0 \\
\hline Pica pica & 4 & 0 & 4 & 0,01 & 0 \\
\hline Picus canus & 4 & 0 & 4 & 0,01 & 0 \\
\hline Turdus viscivorus & 3 & 0 & 3 & 0,01 & 0 \\
\hline Milvus milvus & 3 & 3 & 0 & 0,01 & 0 \\
\hline Streptopelia turtur & 3 & 0 & 3 & 0,01 & 0 \\
\hline Hirundo rustica $x$ Delichon urbicum & 3 & 0 & 3 & 0,01 & 0 \\
\hline Strix uralensis & 3 & 2 & 1 & 0,01 & 0 \\
\hline Lanius excubitor & 3 & 0 & 3 & 0,01 & 1 \\
\hline Ciconia nigra & 2 & 2 & 0 & 0,00 & 1 \\
\hline Columba oenas & 2 & 2 & 0 & 0,00 & 0 \\
\hline Phylloscopus inornatus & 2 & 0 & 2 & 0,00 & 0 \\
\hline Corvus corax & 2 & 1 & 1 & 0,00 & 0 \\
\hline Cuculus canorus & 2 & 1 & 1 & 0,00 & 0 \\
\hline Glaucidium passerinum & 2 & 0 & 2 & 0,00 & 0 \\
\hline Anthus spinoletta & 2 & 0 & 2 & 0,00 & 0 \\
\hline Carduelis flammea cabaret & 2 & 0 & 2 & 0,00 & 0 \\
\hline Lullula arborea & 2 & 0 & 2 & 0,00 & 0 \\
\hline Chroicocephalus ridibundus & 1 & 1 & 0 & 0,00 & 14 \\
\hline Corvus frugilegus & 1 & 1 & 0 & 0,00 & 0 \\
\hline Actitis hypoleucos & 1 & 0 & 1 & 0,00 & 0 \\
\hline Tringa ochropus & 1 & 0 & 1 & 0,00 & 0 \\
\hline Tringa nebularia & 1 & 0 & 1 & 0,00 & 0 \\
\hline Anthus cervinus & 1 & 0 & 1 & 0,00 & 0 \\
\hline Lymnocryptes minimus & 1 & 0 & 1 & 0,00 & 0 \\
\hline Nucifraga caryocatactes & 1 & 0 & 1 & 0,00 & 0 \\
\hline Aegolius funereus & 1 & 0 & 1 & 0,00 & 0 \\
\hline Sterna hirundo & 1 & 1 & 0 & 0,00 & 1 \\
\hline Oenanthe oenanthe & 1 & 0 & 1 & 0,00 & 0 \\
\hline Dryocopus martius & 1 & 0 & 1 & 0,00 & 0 \\
\hline Ardea cinerea & 1 & 0 & 1 & 0,00 & 2 \\
\hline Otus scops & 1 & 0 & 1 & 0,00 & 0 \\
\hline 151 druhov & 59472 & 5641 & 53831 & & 5778 \\
\hline
\end{tabular}

